\title{
A Case of Pseudoaldosteronism Due to Addiction of Jintan, a Mouth Refresher Popular among Japanese
}

\author{
Hiroko Kamei, M.D. and Kikuo Arakawa, M.D.
}

\begin{abstract}
SUMmaRY
A 50-year-old man with hypertension showed hypokalemia, hyporesponsive low reninemia, and low levels of aldosterone in the plasma and urine. Plasma DOG and corticosterone level, adrenal scintigram, and phlebogram were within normal limits. Hypertension and hypokalemia were correctable by spironolactone. It was revealed that he had been ingesting Jintan granules in large doses, corresponding to $150-220 \mathrm{mg}$ of glycyrrhizic acid per day for 10 years. Upon cessation of Jintan ingestion, blood pressure and serum potassium level were normalized after 40 days. Metabolic alkalosis, hypervolemia, hyporesponsive low reninemia, and the low levels of plasma and urine aldosterone were also improved. Thus, the present case of pseudoaldosteronism was attributed to Jintan, and raises a caution to excessive Jintan ingestion.
\end{abstract}

\section{Additional Indexing Words:}

Low renin hypertension Licorice Glycyrrhizin Glycyrrhetinic acid Pseudoaldosteronism Jintan

\footnotetext{
CLYCYRRHIZA extract, more commonly known as licorice extract, is $\checkmark$ produced by aqueous extraction of the dried roots of the plant, Glycyrrhiza glabra. It is used widely as a flavouring in foods and candy, and medically as a mild expectorant and vehicle for masking the unpleasant taste of some pharmaceutical compounds in Chinese remedies. The main component of licorice is glycyrrhizin, a conjugate of 2 molecules of glucuronic acid and glycyrrhetinic acid, which is close to DOC in structure (Fig. 1).11 In 1950, it was reported that both licorice extract and ammonium glycyrrhizate, like DOC, cause increases in systolic blood pressure, potassium excretion, and sodium retention in normal subjects. ${ }^{2)}$ These observations were extended by Louis and Conn, who confirmed in normal subjects that glycyrrhizic acid is the electrolyte-active principle of licorice. ${ }^{3}$ )

In 1968, Conn et al reported a case of pseudoaldosteronism, apparently

From the Department of Internal Medicine, Fukuoka University School of Medicine, 34 Nanakuma, Fukuoka 814, Japan.

Received for publication August 7, 1981.
} 


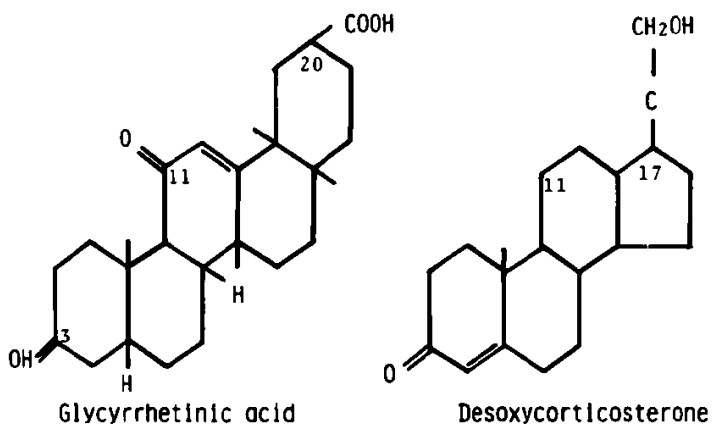

Fig. 1. Structure of glycyrrhetinic acid and desoxycorticosterone.

caused by chronic, excessive licorice ingestion over a period of 7 years. ${ }^{41}$ Hypertension was associated with hypokalemia, alkalosis, and a suppressed renin-angiotensin-aldosterone system (RAA).4,5) Metabolic balance studies recorded complete recovery upon cessation of licorice ingestion. The present case is very similar to Conn's case, but the source of glycyrrhizate was Jintan instead of licorice candy. This report presents our extensive observation on fluid and electrolyte balance, blood pressure, and RAA in this patient.

\section{CASE REPORT}

A 50-year-old man was admitted to the Fukuoka University Hospital on April 7, 1978 because of myalgia and hypertension. There was no history of hypertension in his family. At the age of 18 , hypertension was incidentally noted by a doctor for the first time, but he was not given any antihypertensive drugs because of no complaints. At the age of 49 , he had myalgia, thirst, and polydipsia. Moreover, changes in personality and abnormal behavior were reported by his family. Two months of antihypertensive therapy did not alleviate his hypertension, and, hypokalemia and low plasma renin activity (PRA) were noted by a local physician. A careful history taken after admission, revealed that the patient began ingesting Jintan at 18 years of age, that he had been ingesting extraordinary daily doses of Jintan (750-1,100 granules) for the past 10 years.

On examination, his height was $156.0 \mathrm{~cm}$, and his weight was $60 \mathrm{Kg}$. His face was a mask like. His blood pressure was 202/120 mmHg and pulse rate $68 / \mathrm{min}$ and regular. No pigmentation was found on either the skin or mucous membrane. Stage II hypertensive changes were noted in the optic fundi. There were no pathological findings in the neck, chest, abdomen, and extremities. There were neither sexual abnormalities nor abnormal neurological findings. 
Laboratory studies disclosed the following: erythrocyte sedimentation rate was $22 \mathrm{~mm} / \mathrm{hr}$, hematocrit $35.3 \%$, serum Na $146 \mathrm{mEq} / \mathrm{L}$, Serum K 2.5 $\mathrm{mEq} / \mathrm{L}$, and serum $\mathrm{Cl} 97 \mathrm{mEq} / \mathrm{L}$. The urine contained a slight proteinuria and microhematuria. Arterial blood gas showed metabolic alkalosis $(\mathrm{pH}$ 7.48 , base excess +10 ). A $50 \mathrm{Gm}$ glucose tolerance test was normal. Creatinine clearance was $68 \mathrm{ml} / \mathrm{min}$. The PSP excretion in $15 \mathrm{~min}$ was $24.5 \%$ and the maximum specific gravity of urine was 1.016. Urinary potassium excretion was $33.5 \mathrm{mEq} /$ day, and potassium clearance by the use of sodium thiosulfate was relatively high, $29.5 \mathrm{ml} / \mathrm{min}$. His circulating plasma volume was $55 \mathrm{ml} / \mathrm{Kg}$. Thyroid hormone $\left(T_{3}\right.$ and $\left.T_{4}\right)$ levels and urinary vanillyl mandelic acid (VMA) excretion were normal. Roentgenograms of the chest and abdomen were within normal limits. Electrocardiography showed left ventricular hypertrophy, an abnormal $U$ wave and a flat $T$ wave, probably due to hypokalemia. Results of an intravenous pyelogram were within normal limits.

\section{$R A A$}

Under salt restriction of $6 \mathrm{Gm} /$ day, the fasting plasma renin activity (PRA) at rest was close to the detectable limit $(0.1 \mathrm{ng} / \mathrm{ml} / \mathrm{hr})$. It responded little and increased to $0.2 \mathrm{ng} / \mathrm{ml} / \mathrm{hr}$ after ambulation for 2 hours, to $0.25 \mathrm{ng} /$ $\mathrm{ml} / \mathrm{hr}$ after 3 days on a salt free diet, and to 0.46 after ambulation for 2 hours and administration of $40 \mathrm{mg}$ of furosemide IV. The plasma aldosterone concentration (PAC) and urinary aldosterone excretion were suppressed to 6.0 $\mathrm{ng} / 100 \mathrm{ml}$ and near detectable limit $(1 \mu \mathrm{g} /$ day $)$, respectively. Furthermore, a salt free diet for 3 days plus furosemide IV did not alter these values.

\section{Steroid hormone study}

The plasma cortisol level was $16.0 \mu \mathrm{g} / 100 \mathrm{ml}$, and the plasma ACTH level was $62 \mathrm{pg} / \mathrm{ml}$. The urinary 17-hydroxycorticosteroids (17-OHCS) level was $8.0 \mathrm{mg} /$ day and urinary 17 -ketosteroids (17-KS) were at a level of 5.8 $\mathrm{mg} / 100 \mathrm{ml}$. All these steroids were within normal limits. Among the well

Table I. Adrenal Venous Aldosterone, DOC and Corticosterone Levels

\begin{tabular}{|c|c|c|c|}
\hline $\begin{array}{l}\text { Positlon } \\
\text { of blood sampling }\end{array}$ & $\begin{array}{r}\text { Aldosterone } \\
(\mathrm{Dg} / \mathrm{ml})\end{array}$ & $\begin{array}{r}\text { Corticosterone } \\
(\mathrm{ng} / \mathrm{ml})\end{array}$ & $\begin{array}{l}\text { DOC } \\
\text { (ng/ml) }\end{array}$ \\
\hline Right renal veln & $<20$ & 0.901 & 0.363 \\
\hline Left renal vein & $<20$ & 1.33 & 3.21 \\
\hline Right adrenal vein & 56.1 & 2.31 & 0.397 \\
\hline Left adrenal veln & 20 & 2.16 & 0.863 \\
\hline Infertor veno covo & $<20$ & 0.681 & 0.993 \\
\hline Cubltol ve1n & 31,4 & 1.46 & 0.831 \\
\hline
\end{tabular}


known mineralocorticoids, the plasma deoxycorticosterone (DOC) level was $0.187 \mathrm{ng} / \mathrm{ml}$ and plasma corticosterone level $1.46 \mathrm{ng} / \mathrm{ml}$, all within normal limits. So were the adrenal venous aldosterone, DOC, and corticosterone level (Table I). Neither an adrenal scintigram nor a phlebogram showed any abnormalities.

\section{Dexamethasone test}

Dexamethasone ( $2 \mathrm{mg} /$ day) was administered for 14 days, but the blood pressure did not respond (Fig. 2). The serum potassium level increased from 2.6 to $3.0 \mathrm{mEq} / \mathrm{L}$. Although there was a small change in PRA (from 0.2 to $0.25 \mathrm{ng} / \mathrm{ml} / \mathrm{hr}$ ) and no changes in urinary aldosterone excretion $(<1 / \mathrm{g} /$ day $)$ were obtained, PAC decreased from 12.5 to $5.2 \mu \mathrm{g} / 100 \mathrm{ml}$.

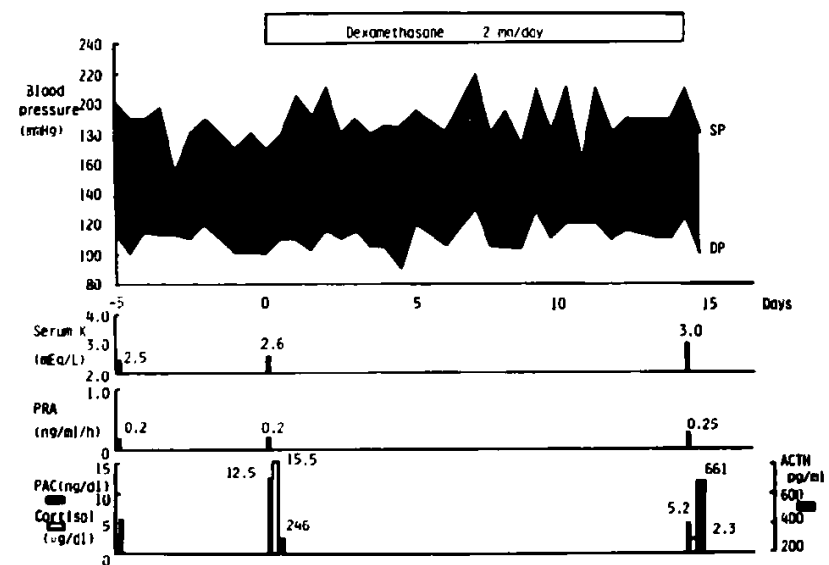

Fig. 2. Effects of dexamethasone on blood pressure, serum potassium, PRA, PAC, plasma cortisol, and ACTH levels.

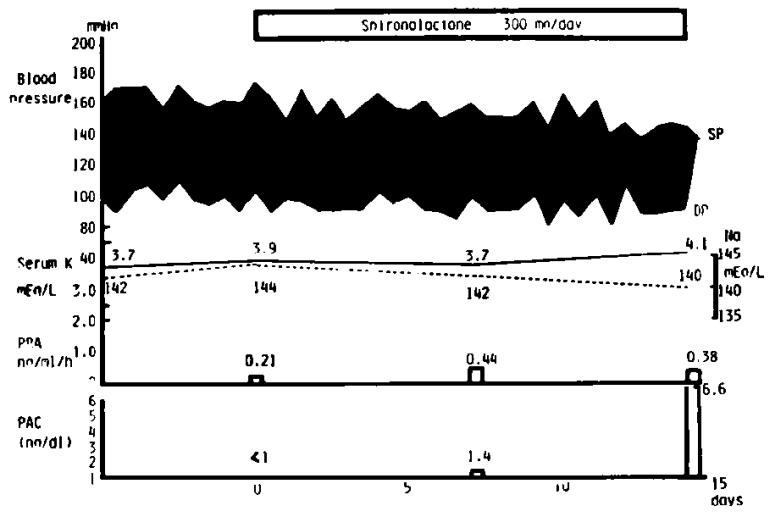

Fig. 3. Effects of spironolactone on blood pressure, serum potassium, PRA, and PAC. 


\section{Treatment with spironolactone}

Spironolactone $(300 \mathrm{mg} /$ day $)$ was administered for 14 days. Systolic blood pressure reduced from 170 to $142 \mathrm{mmHg}$ and diastolic blood pressure from 110 to $90 \mathrm{mmHg}$ (Fig. 3). The serum potassium level increased from 3.7 to $4.1 \mathrm{mEq} / \mathrm{L}$ and the serum Na level decreased from 144 to $140 \mathrm{mEq} / \mathrm{L}$. Although PRA rose from 0.21 to $0.38 \mathrm{mg} / 100 \mathrm{ml} / \mathrm{hr}$ and PAC from the detectable limit $(1 \mathrm{ng} / 100 \mathrm{ml})$ to $6.6 \mathrm{ng} / 100 \mathrm{ml}$, respectively, urinary aldosterone excretion did not change $(<1 \mu \mathrm{g} /$ day $)$.

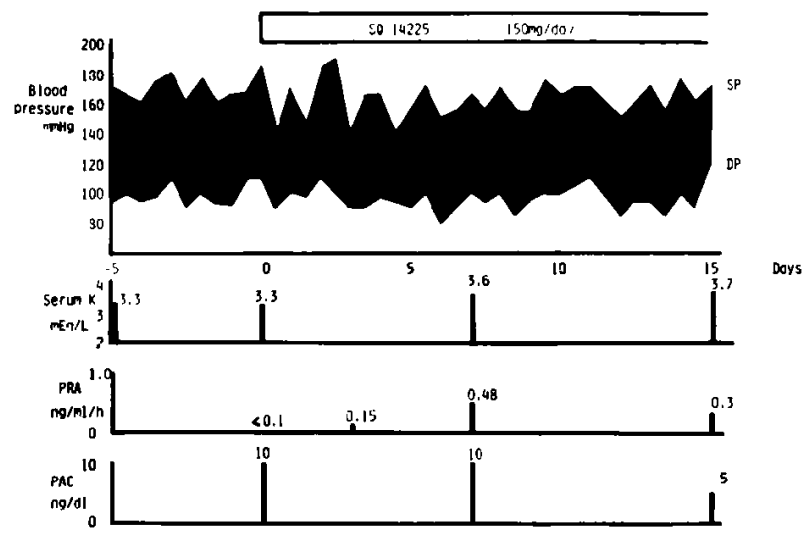

Fig. 4. Effects of converting enzyme inhibitor (SQ14225) on blood pressure, PRA, and PAG.

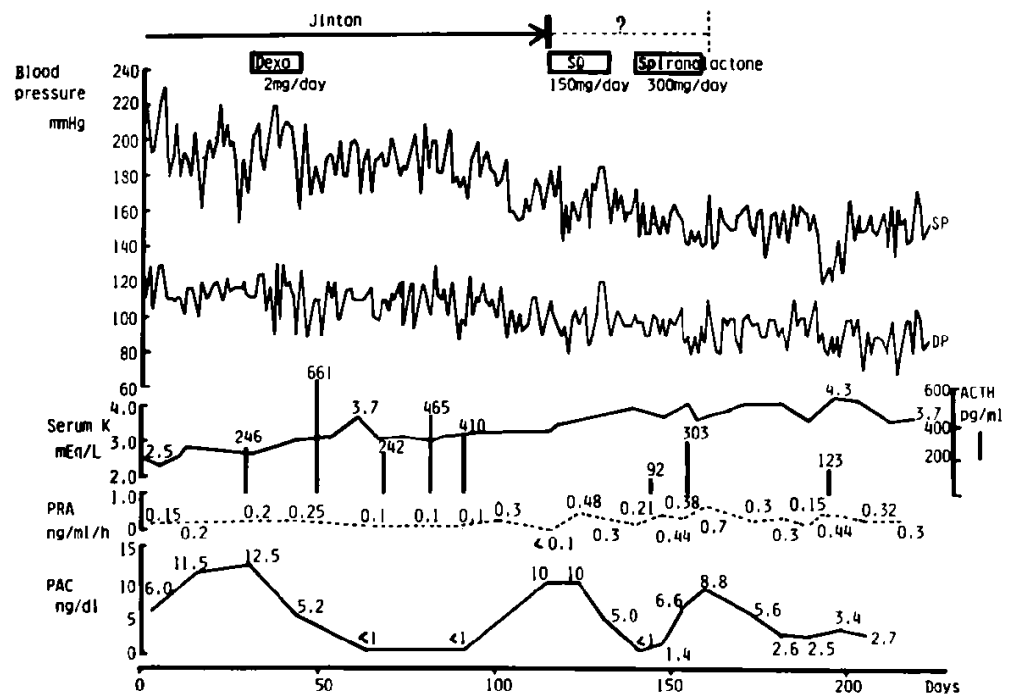

Fig. 5. Effects of the administration and the cessation of Jintan on blood pressure, serum potassium, PRA, PAC, and plasma ACTH levels. 
Table II. The Effect of the Cessation of Jintan on the Laboratory Findings

\begin{tabular}{|c|c|c|c|}
\hline & $\begin{array}{c}\text { During Injestion } \\
\text { of Jinton }\end{array}$ & $\begin{array}{l}\text { After cess } \\
\text { of Jinto }\end{array}$ & ot lon \\
\hline $\begin{array}{l}\text { Serum Na level } \\
\text { Serum } K \text { level }\end{array}$ & $\begin{array}{r}146 \\
2.5\end{array}$ & $\begin{array}{l}141 \\
3.7\end{array}$ & $\begin{array}{l}m E q / L \\
m E q / L\end{array}$ \\
\hline $\begin{array}{l}\text { Urinory excretion of No } \\
\text { Urinary excretion of } k\end{array}$ & $\begin{array}{l}43.6 \\
33.5\end{array}$ & $\begin{array}{l}76 \\
21.85\end{array}$ & $\begin{array}{l}\mathrm{mEq} / \text { day } \\
\mathrm{mEq} / \text { day }\end{array}$ \\
\hline $\mathrm{K}$ clearance & 29.5 & 14.05 & $\mathrm{ml} / \mathrm{mln}$ \\
\hline Flshberg concentration test & 1016 & 1027 & \\
\hline $\begin{array}{l}\text { DH of orteriol blood gos } \\
\text { BE of orterlal blood gos }\end{array}$ & $\begin{array}{r}7.48 \\
+10.0\end{array}$ & $\begin{array}{r}7.41 \\
+1.3\end{array}$ & \\
\hline Circuloting plasmo volume & 3300 & 2568 & $\mathrm{ml}$ \\
\hline $\begin{array}{ll}\text { Plosmo renin activity } & \text { before } \\
\text { Furosemide IV } & \text { ofter }\end{array}$ & $\begin{array}{l}0.3 \\
0.46\end{array}$ & $\begin{array}{l}0.44 \\
1.25\end{array}$ & $\mathrm{ng} / \mathrm{ml} / \mathrm{h}$ \\
\hline $\begin{array}{l}\text { Plosma oldosterone concentrotion } \\
\text { Urinary excretion of aldosterone }\end{array}$ & $\begin{array}{r}6.0 \\
<1\end{array}$ & $\begin{array}{l}5.6 \\
2.9\end{array}$ & $\begin{array}{l}\mathrm{ng} / \mathrm{dl} \\
\mu \mathrm{g} / \mathrm{day}\end{array}$ \\
\hline $\begin{array}{ll}\text { Plosmo anglotens In I } & \text { level } \\
\text { Plosmo anglotensin II } & \text { level }\end{array}$ & $\begin{array}{l}25 \\
15\end{array}$ & $\begin{array}{l}25 \\
30\end{array}$ & $\begin{array}{l}\mathrm{pg} / \mathrm{ml} \\
\mathrm{Dg} / \mathrm{ml}\end{array}$ \\
\hline Plosmo ACTH level & 246 & 123 & $\mathrm{Dg} / \mathrm{ml}$ \\
\hline
\end{tabular}

Treatment by converting enzyme inhibitor (SQ14225 or Captopril)

A converting enzyme inhibitor, captopril, was administered for 14 days (150 mg/day t.i.d.). Systolic blood pressure decreased from 184 to 160 $\mathrm{mmHg}$ and diastolic blood pressure decreased from 100 to $90 \mathrm{mmHg}$ (Fig. 4). The serum potassium level increased from 3.3 to $3.7 \mathrm{mEq} / \mathrm{L}$ after 14 days of captopril treatment. PRA rose from the detectable limit to $0.3 \mathrm{ng} /$ $\mathrm{ml} / \mathrm{hr}$. PAC decreased from 10 to $5 \mathrm{ng} / 100 \mathrm{ml}$, but urinary aldosterone excretion did not change $(<1 \mu \mathrm{g} /$ day $)$.

Cessation of Jintan

Forty days after cessation of Jintan, systolic blood pressure declined from 220 to $120 \mathrm{mmHg}$, diastolic blood pressure decreased from 120 to $80 \mathrm{mmHg}$, the serum potassium level rose from 2.5 to $4.3 \mathrm{mEq} / \mathrm{L}$ and the serum $\mathrm{Na}$ level decreased from 146 to $139 \mathrm{mEq} / \mathrm{L}$ (Fig. 5). As shown in Table II, all the features of this case i.e., hypokalemic alkalosis, increased potassium excretion, hypotonic urine, increased circulating plasma volume, and suppressed RAA were within normal limits.

\section{Discussion}

The hypertension in the present case was volume dependant with low PRA and hypokalemic alkalosis, and, therefore, primary aldosteronism was 
suspected. But, neither an excess of steroids nor an adrenal tumor or hyperplasia were found. After a careful probing of his history, it was revealed that he had been ingesting extraordinary doses of Jintan. Since Jintan contains licorice, a steroid-related substance having mineralocorticoid like activities, he is diagnosed as a case of pseudoaldosteronism due to excessive intake of Jintan.

Administration of dexamethasone improved neither blood pressure nor PRA and low level of aldosterone in the urine, although the serum potasssium level increased slightly and PAC decreased. This was probably due to suppression of ACTH (Fig. 2). Administration of spironolactone relieved both hypokalemia and hypertension. Moreover, it brought about an increase in PRA and PAC (Fig. 3), as reported by Salassa in 1962.6) It was extremely difficult to force the patient to cease Jintan ingestion completely, as shown by question mark and dotted line in Fig. 5, but the cessation of Jintan most dramatically improved all pathological features of this patient, such as hypervolemic hypertension, hypokalemic alkalosis, and low PRA in 40 days. Thus, it has been inferred that hypertension was associated with chronic excessive ingestion of Jintan. Jintan is one of the most popular mouth refreshers or appetitives among Japanese. One granule of Jintan contains $5.10 \mathrm{mg}$ of licorice which contains $0.20 \mathrm{mg}$ of glycyrrhizic acid. The 750 to 1,100 granules which the patient had been ingesting a day correspond to $150-220 \mathrm{mg}$ of glycyrrhizic acid.

Glycyrrhizic acid, active component of licorice, has aldosterone-like activities and, when ingested in large quantities, it produces symptoms similar to an excess of mineralocorticoids. Glycyrrhizic acid acts directly on renal tubules and causes $\mathrm{Na}$ retention and potassium diuresis. ${ }^{7,8)}$ As glycyrrhizic acid competitively inhibits the degradation of all kinds of steroid hormones composing $J^{4}-3$ ketone, ${ }^{9,10)}$ it is considered that the actions of these steroid hormones are potentiated. In addition, licorice would probably disturb steroid metabolism in the liver, so steroid hormones remained in the circulating blood for a longer time. In our case, urinary aldosterone excretion was very low and unresponsive to various stimulation, in comparison to PAC, during ingestion of Jintan. Therefore, the effects of mineralocorticoids might be accerelated. Although the mechanism for the hypertension resulting from excess of licorice can not be fully defined, pseudoaldosteronism is closely analogous to primary aldosteronism, except for a very low or undetectable amount of aldosterone in the urine and blood. ${ }^{4), 5), 111}$

In Japan, the use of glycyrrhizic acid and its derivatives, which are active component of licorice, are widely indicated for various diseases such as allergic dermatitis and chronic hepatitis, in expectation of a glucocorticoid-like action. 
For this reason, incidence of pseudoaldosteronism has tended to increase recently, and there are already 8 reports of pseudoaldosteronism induction. ${ }^{12)-19}$ )

Present report emphasizes the importance of ruling out licorice ingestion in the differential diagnosis of the hypokalemic hypertensive patients with low PRA. It also demonstrates the diagnostic value of low levels of both aldosterone secretion and PRA in this condition, which may give a clue in diagnosis. This may be especially important in Japan and Oriental countries, where nearly $70 \%$ of Chinese medications contain licorice as an ingredient, and are used commonly without any restrictions.

\section{Conclusion}

A case of pseudoaldosteronism was studied. A detailed history revealed that the patient has been ingesting 750-1,100 granules of Jintan, or 150-220 mg of glycyrrhizic acid daily for 10 years. After complete cessation of Jintan ingestion, all pathological features such as high blood pressure, hypokalemia, alkalosis, and low PRA and aldosterone secretion were normal in 40 days.

\section{REFERENCES}

1. Ruzicka L, Luenberger H: Polytepene und polyterpenoide CIX. Zur Kenntiss der glycyrrhetinsäure. Helv Chim Acta 19: 1402, 1936

2. Molhuysen JA, Gerbandy J, de Vries LA, de Jong JC, Lenestra JB, Turner KP, Borst JGG: A licorice extract with desoxycorticosterone like action. Lancet 2: 381, 1950

3. Louis LH, Conn JW: Preparation of glycyrrhizinic acid, the electrolyte active principle of licorice. Its effects upon metabolism and upon pituitary adrenal function in man. $\mathrm{J}$ Lab Clin Med 47: 20, 1956

4. Conn JW, Rovner DR, Cohen EL: Licorice induced pseudoaldosteronism. JAMA 205: 492, 1968

5. Conn JW, Cohen EL, Rovner DR: Suppression of plasma renin activity in primary aldosteronism. Distinguishing primary from secondary aldosteronism in hypertensive disease. JAMA 19: 213, 1964

6. Salassa RM, Mattox VR, Rosevear JW: Inhibition of the " mineralocorticoid " activity of licorice by spironolactone. J Clin Endocr 22: 1156, 1962

7. Groen J, Pelsmer H, Frenkel M, Kumminga CE, Willebrands AF: Effect of glycyrrhetinic acid on the electrolyte metabolism in Addisoin's disease. J Clin Invest 31 : 87, 1952

8. Ulmann A, Menard J. Corvol P: Binding of glycyrrhetinic acid to kidney mineralocorticoid and glucocorticoid receptors. Endocrinology 97: 46, 1975

9. Kumagai A, Yano S, Otomo M, Takeuchi K: Study on the corticoid-like action of glycyrrhizin and the mechanism of its action. Endocrinol Japan 4: 17, 1957

10. Aterden LM: Studies with glycyrrhetinic acid. Inhibition of metabolism of steroids in vitro. Biochem J 69: 75, 1958

11. Holmes AM, Marrot PK: Pseudoaldosteronism induced by habitual ingestion of licorice. Postgrad Med J 46: 625, 1970

12. Kim KS, Yamamoto Y, Miyamori Y, Uchida K, Saito Z, Morimoto S, Takeda R: A case of pseudoaldosteronism induced by glycyrrhizin. Int Med 39: 880, 1977 (in Japanese) 
13. Sugita M, Otsuru N, Horai Z: A case of licorice induced pseudoaldostcronism. J Jap Soc Int Med 63: 1312, 1974

14. Hanasaki N, Kato H, Shinomura Y, Nakao K, Morimoto Y, Yano S: A case of pseudoaldosteronism induced by large doses of glycyrrhizin. Jap J Clin Med 34: 390, 1976

15. Yamashita K, Matsuyama I, Saruwatari K, Kamura S, Hamano H: A case of pseudoaldosteronism induced by glycyrrhizin. J Jap Soc Int Med 65: 518, 1976

16. Takekoshi T, Takeuchi N, Imura S, Ibata $\mathrm{T}$, Onchi $\mathrm{K}$ : A case of pseudoaldosteronism induced by large doses of glycyrrhizin. J Jap Soc Int Med 66: 581, 1977

17. Konishi T, Morizane T, Saruta T, Ozawa Y, Kato E: A case of pseudoaldosteronism induced by glycyrrhizin. J Jap Soc Int Med 66: 576, 1977

18. Kimura K, Inoue K, Ishii A, Ikeda S, Matsuoka H, Shimomura K, Murao S: A case of licorice induced pseudoaldosteronism. J Jap Soc Int Med 66: 576, 1977

19. Mitsumoto H, Kanemoto N, Ide M, Kobayashi T: A case of ventricular flutter and fibrillation due to glycyrrhizin induced pseudoaldosteronism. Respiration and Circulation 28: 169, 1980 (in Japanese) 